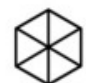 \\ LEUPHANA \\ UNIVERSITÄT LÜNEBURG
}

Sense, seize, reconfigure

Wagner, David; Wenzel, Matthias; Wagner, Heinz Theo; Koch, Jochen

Published in:

Journal of Business Strategy

DOI:

10.1108/JBS-09-2016-0088

Publication date:

2017

\section{Document Version}

Publisher's PDF, also known as Version of record

Link to publication

Citation for pulished version (APA):

Wagner, D., Wenzel, M., Wagner, H. T., \& Koch, J. (2017). Sense, seize, reconfigure: Online communities as strategic assets. Journal of Business Strategy, 38(5), 27-34. https://doi.org/10.1108/JBS-09-2016-0088

\section{General rights}

Copyright and moral rights for the publications made accessible in the public portal are retained by the authors and/or other copyright owners and it is a condition of accessing publications that users recognise and abide by the legal requirements associated with these rights.

- Users may download and print one copy of any publication from the public portal for the purpose of private study or research.

- You may not further distribute the material or use it for any profit-making activity or commercial gain

- You may freely distribute the URL identifying the publication in the public portal ?

If you believe that this document breaches copyright please contact us providing details, and we will remove access to the work immediately and investigate your claim. 


\title{
Sense, seize, reconfigure: online communities as strategic assets
}

\author{
David Wagner, Matthias Wenzel, Heinz-Theo Wagner and Jochen Koch
}

\section{Introduction}

Information technologies play an increasingly important role for the management of modern organizations, creating and capturing value in novel ways by harnessing knowledge resources and (big) data. A noteworthy segment of emerging information technologies is social software, which helps to connect organizational stakeholders in online communities. Prominent examples include company-wide social networking sites and customer-facing brand or innovation communities. As online communities enter the mainstream, they demonstrate their utility primarily for operational purposes, e.g. as extended marketing channels. However, we know little about how organizations may also use online communities strategically.

In this paper, we argue that online communities may be used as strategic vehicles, helping organizations adapt to a changing business environment. We believe that online communities should constitute a key component of any organization's digital business strategy.

\section{Online communities}

Sproull and Arriaga (2007, p. 898) define online communities as collectives of "voluntary members whose primary goal is member and collective welfare, whose members share a common interest, experience, or conviction and positive regard for other members, and who interact with one another and contribute to the collectivity primarily over the Net". Research shows that online communities constitute rich communication environments for organizations and afford behaviors that were not possible with previous forms of computer-mediated communication (Wagner et al., 2014). For example, content produced in online communities is generally visible to all members and remains visible over time. Associations can be made between people and content (e.g. certain areas of expertise) or through connections between people (e.g. communities of practice). Members of online communities may edit and update the content, which enables them to dynamically create and re-create knowledge objects (e.g. through revisions). Due to these characteristics, online communities are suited specifically for knowledge collaboration among stakeholders, such as employees, customers and the public (Faraj et al., 2011).

\section{Online communities and strategic management}

In the field of strategy, researchers have yet to incorporate the opportunities and challenges of online communities into their work (Haefliger et al., 2011). The first publications available focus specifically on the resolution of firm boundaries and organizational hierarchies, i.e. issues surrounding organizational design (Gulati et al., 2012). Consider Wikipedia, the encyclopedia or Mozilla, producer of the web browser Firefox. Both organizations are open
David Wagner is

Assistant Professor at the German Graduate School of Management and Law, Heilbronn, Germany. Matthias Wenzel is PostDoctoral Researcher at European University Viadrina, Frankfurt, Germany.

Heinz-Theo Wagner is Professor at the German Graduate School of Management and Law, Heilbronn, Germany. Jochen Koch is Professor at European University Viadrina, Frankfurt, Germany.
(C) David Wagner, Matthias Wenzel, Heinz-Theo Wagner and Jochen Koch. Published by Emerald Publishing Limited. This article is published under the Creative Commons Attribution (CC BY 4.0) licence. Anyone may reproduce, distribute, translate and create derivative works of this article (for both commercial \& non-commercial purposes), subject to full attribution to the original publication and authors. The full terms of this licence may be seen at: http:// creativecommons.org/licences/ by/4.0/legalcode 


\section{"Through the online community, BMW aims at supporting the generation of new ideas, in both quantitative and qualitative terms."}

communities where boundaries are permeable and decision-making structures are flat. They may be considered new archetypes of organizations whose design logics in terms of control, labor division and rewards are fundamentally different from those of traditional organizations (Puranam et al., 2014). The research cited above highlights the relevance of online communities in the arena of organizational design. In this paper, however, we will focus on the potential of online communities to contribute to an organization's ability to respond to a changing business environment. To illustrate how organizations can use online communities for this purpose, we draw on the dynamic capabilities concept, which operationalizes an organization's adaptation process in terms of a set of capabilities.

\section{Dynamic capabilities}

The central tenet of dynamic capabilities is to explain how organizations may dynamically adapt and align their routines and resources to achieve a competitive advantage (Teece et al., 1997). Helfat and Peteraf (2009, p. 91) state that this quest "might well be characterized as the Holy Grail of strategic management". According to Teece (2007), dynamic capabilities can be defined in terms of sensing, seizing and reconfiguring. Sensing comprises "analytical systems to learn and to sense, filter, shape, and calibrate opportunities". Thus, sensing includes all processes that help an organization collect and analyze market information to learn about customers, competitors and channel members. Seizing relates to addressing sensed opportunities "through new products, processes, or services". Therefore, seizing typically evokes increased research and development activities. Reconfiguring refers to an "ability to recombine and to reconfigure assets and organizational structures" to match the organization's internal processes with seized opportunities. It may, thus, involve changes in the business model, mergers, acquisitions and divestments (Teece, 2010).

This set of capabilities provides an analytical framework that helps to capture how organizations adapt and respond to a changing business environment. We use this analytical framework to explore and illustrate how organizations may use online communities for this purpose.

\section{Data collection and analysis}

To gain rich insights into a new phenomenon, the context of online communities, we conducted a multiple-case study following the approach put forward by Yin (2014). Case studies are particularly suited to answer "how" questions, as is the case in this paper. For the identification of appropriate cases, we relied on referrals by the management board of the German Association for Community Management, a professional association. All individual members of the association are in charge of an online community and have considerable expertise regarding the functioning and use of their respective communities. In preliminary talks with several online community members, we followed a theoretical sampling strategy (Miles and Huberman, 1994), searching for cases that illuminated the strategic use of online communities particularly well and in different ways. This resulted in a sample of three cases that fulfilled these criteria.

To facilitate the triangulation of evidence, we relied on several data sources (Yin, 2014). Our primary data source was a 60- to 90-min interview with an online community manager of 
each organization consisting of five sections: personal information on the interviewee and the online community management (team) of the organization, background information on the firm and its competitive positioning, details about the business environment and its dynamism, details about the online community and its functioning and business impacts of the online community. Further data sources included archival data from corporate documents, such as websites, press releases and annual reports, observations from company visits and follow-up emails and phone calls. Several of the selected organizations had previously been involved in university collaborations, and we also had various published and unpublished studies available for inspection. In addition, we collected reports from industry associations.

Following the transcription of the interviews, we imported all material into a software package for qualitative data analysis and examined the data deductively, i.e. we specifically focused on Teece's (2007) classification of dynamic capabilities as sensing, seizing and reconfiguring. Once we identified these capabilities in our data, we examined how online communities became relevant to the organizations relative to these capabilities.

\section{Case 1: Sensing opportunities and threats with a customer community}

The first online community is a virtual customer community. The online community is hosted by notebooksbilliger, a leading retailer in Germany. In 2015, the host organization generated revenues of about $€ 700 \mathrm{~m}$. It currently employs more than 300 individuals, with a majority working in the logistics department. notebooksbilliger sells electronic equipment of all types, but its core products are notebooks and cell phones. It started with a focus on notebooks only. Yet, as the German notebook market is nearing saturation, the company increasingly turned to complementary product offers. In terms of revenue, notebooksbilliger is currently the fourth biggest online retailer and the leader in the field of consumer electronics in Germany.

The company's strategy is focused on price leadership. However, notebooksbilliger also attempts to offer the most complete product descriptions and reviews in addition to the lowest price. This is where the online community enters the scene. The company's multiple objectives for the customer community are to convert potential customers into clients, to reduce the number of product returns after delivery and to enhance the organization's visibility on the Web in the form of search engine optimization. The online community is run by a team of four community managers who report to the marketing and communications department.

The customer community has three components: a blog, a forum and product evaluations. The blog serves as an information and communication channel for corporate issues. In the forum, which is closely tied to the online shop, anyone can post questions regarding a product or its features. Typically, customers post questions to the online community shortly before or after a purchase. In the former case, customers regularly seek additional information regarding product features. In the latter case, they inquire about issues they have with previously purchased items. After a completed purchase, customers can also evaluate the product purchased. In terms of activity, there are about 4,000 posts per month in the forum. As no registration is required to post to the forum, anonymous posting makes it impossible to determine the online community's exact number of members.

\section{"WVW introduced value co-creation with help of the citizen community."}




\section{"Successful digital business strategies do not treat online communities merely as an extended marketing channel."}

notebooksbilliger uses the online community as a communication device to sense customer preferences and trends. The community management team acts as an information filter. It collects, analyzes and distills relevant information from the online community. The lead community manager reports:

We recently switched shipping services from DHL to UPS. We now also offer deliveries via Hermes. It was my task to see how people would react to these changes, whether there were any complaints. If so, I would need to speak to the board of directors to let them know what isn't working.

As this quote implies, the lead community manager sits on both the strategy and the innovation committees in his company, guaranteeing that he can pass on information to the board of directors. "This is the reason why I'm invited to such meetings. I realize very quickly when things go wrong".

In addition, notebooksbilliger prides itself on being able to predict market trends well. According to the lead community manager, the customer community plays an integral role in this regard. For example, the online community helped notebooksbilliger venture into the smartphone market early on when the online community management team realized that customer preferences were changing in its favor. Smartphones now constitute a significant portion of the company's income stream. The same holds for the transition from laptop computers, a saturated market, to mobile digital devices, a growing market. notebooksbilliger is currently considering the introduction of a number of new products into its portfolio. The community management team actively engages its customer community in planning and decision processes:

Recently, we discussed a new shop design. None of us quite agreed with the others. Each of

us had his own take on the decision. In the end, the CEO mandated: Let's ask the community!

The customer community is, thus, the main enabler for customer centricity.

\section{Case 2: Seizing opportunities with an innovation community}

The second online community is an innovation community with 2,500 members. This online community is hosted by the BMW Group, an international manufacturing company with about 120,000 employees and an annual turnover of over $€ 90 b n$ in 2015 . According to a global industry association, the host organization is listed among the 20 most productive manufacturers in the world. It is well positioned in the premium segment of the automotive market.

The strategy of BMW is focused on being an innovation leader. This is where the company's online community becomes relevant. The innovation community is called "RedSquare" and is developed and managed by the company's central innovation department. BMW initiated the online community in 2007 and piloted it within the research and development department. In 2012, the online community was opened to the entire organization. Through the online community, BMW aims at supporting the generation of new ideas, in both quantitative and qualitative terms, and facilitating the collaboration among different types of experts, such as engineers or innovators. The design of the innovation community supports interactive value creation by using well-known features from other social software applications. For example, employees may create profiles where they can include information about areas of expertise, 
projects they are currently working on and subject areas they are interested in. They may then connect to other employees, post project ideas, either anonymously or under their real name, and attach files, such as project presentations or patents already issued. In the vein of open innovation, BMW is considering an integration of suppliers and partners into the innovation community.

Especially in the manufacturing industry, intellectual property generation and protection constitute an important ingredient of the value creation process of organizations. New products often require a large number of patented parts. Therefore, once employees of BMW post ideas to the community, the patent department identifies and processes potential innovations. The innovation community, thus, facilitates both idea generation and project management with the goal of speeding up the development of new products and protecting them quickly through securing patents. In this way, it illustrates that organizations can also use online communities to seize business opportunities. In the words of a project manager:

The idea about electric scooter was initially posted to the community. It was taken up by the right people, who were also able to develop the idea further. The project was pitched in the right types of committees, later it received the necessary funding. Ultimately, the electric scooter was developed and prototyped in cooperation with the same people who initially suggested it.

Following the developmental phase, BMW commercialized the electric scooter successfully. Therefore, in line with BMW's strategy of being an innovation leader, the innovation community may be considered a strategic asset in maintaining this leadership role.

\section{Case 3: Reconfiguration of organizational resources with a citizen community}

The third community, a local citizen community called "Lokalkompass" is hosted by the Westdeutsche Verlags- und Werbegesellschaft (WVW). This organization is a subsidiary of the Funke Mediengruppe, a large European publishing group with about 6,000 employees and revenues of more than $€ 1 \mathrm{bn}$. The main products of the publishing house are newspapers, free sheets and magazines. The group also owns a number of radio stations and printing plants. The group's strategy is focused on maintaining and extending its leadership position in the field of regional media production at the intersection of print and digital.

The citizen community is linked to the production of so-called "free sheets", i.e. newspapers that the host organization distributes free of charge and re-finances based on ad revenues. The host organization usually delivers the free sheets once a week in the same distribution area as its main newspapers. $W V W$ develops and produces 73 free sheet titles in 36 local offices, totaling five million copies and reaching a household coverage of 94 per cent. Although the free sheet segment of the industry has been stagnating in terms of revenues, print runs and titles for most of the past decade, WVW's revenues are still positive and significant. Within the free sheet segment, the company ranks first in Germany and first in Europe, thus maintaining a leadership position in the market.

The citizen community was established in 2010 and currently has 28,000 members who may write posts or upload photos, comment on content that others have produced, embed videos, form groups and establish connections with other members of the online community. To date, members have created more than 250,000 posts and have uploaded more than one million pictures. The online community is designed around local districts or neighborhoods, much like the free sheets themselves. Professional editors, jointly with members of the online community, are involved in the generation of local news, e.g. reports about events taking place in a specific neighborhood. 
Therefore, the members of this online community are called "citizen reporters". Popular articles that citizen reporters create online are later published in print in the free sheets. Publication serves as an incentive for participating in this online community, and at the same time, as a sign of appreciation for the content created.

Besides enhancing brand awareness and monetizing the content through ads, WVW attempts to build an online outfit from what used to be a purely offline business by using its online community. Therefore, this case serves as an example of the reconfiguration of organizational resources. While professional editors exclusively produced relevant local content for WVW's free sheets before the publisher introduced its online community, such content is now provided in part by citizen reporters in the community. The lead community manager explained:

[The editors] had to realize that having to take care of the community not only requires additional effort, but has some utility, i.e. the production of user-generated content. [ . . ] That was what we

had to make them aware of. Use it! Use the information provided!

In comparison to the old business model, WVW's professional editors and readers of the free sheets now generate value jointly. In essence, WVW introduced value co-creation with help of the citizen community. The World Association of Newspapers and News Publishers has recently awarded WVW a prize for their community engagement.

Table I provides an overview of our analysis for the three cases discussed above.

\section{Conclusion}

In this paper, we explore and illustrate how organizations may use online communities strategically to adapt to a changing business environment. Drawing on dynamic capabilities as our analytical framework, the presented cases illustrate that organizations may use online communities to:

- sense opportunities and threats;

- seize opportunities; and

- reconfigure tangible and intangible assets.

In doing so, the paper contributes to the strategy and information systems literature by highlighting and empirically illustrating the strategic role of online communities in organizations.

On a more abstract level, we concur with Oestreicher-Singer and Zalmanson (2013) who emphasize that successful digital business strategies do not treat online communities merely as an extended marketing channel or a technical enhancement of previous products. Instead, they integrate IT-enabled social experiences through online communities into organizations' core products and competencies. Hence, these social experiences may be viewed as intangible resources which help organizations differentiate themselves from others, are difficult to replicate and facilitate the achievement of competitive advantage. Viewed through this lens, online communities constitute an integral component of any organizations' digital business strategy (Bharadwaj et al., 2013). On a

Table I The strategic role of online communities in helping firms adapt to a changing business environment

\section{Case/Community Customer community}

Capability

Manifestation
Sensing opportunities and threats

Understanding customer preferences and New product development trends

Seizing opportunities

\section{Innovation community}

Citizen community

Reconfiguring tangible and intangible assets

Shift from in-house content production to value co-creation

PAGE 32 | JOURNAL OF BUSINESS STRATEGY | VOL. 38 NO. 52017 
more operational level, this paper helps managers and consultants to understand the strategic role online communities (may) play and suggests ways in which they can use online communities strategically.

As for limitations, our focus is on the strategic use of online communities, and we have selected our cases accordingly. However, it is important to note that not all uses of online communities will classify as strategic uses, nor are they always beneficial. It is quite possible that online community adoption is merely a response to overall industry pressure, for example. In addition, online community adoption may also be associated with certain risks, e.g. with regard to the protection of local knowledge assets and the flow of information out of an organization (von Krogh, 2012). Both areas certainly warrant future research.

\section{References}

Bharadwaj, A., El-Sawy, O.A., Pavlou, P.A. and Venkatraman, N. (2013), "Digital business strategy: toward a next generation of insights", MIS Quarterly, Vol. 37 No. 2, pp. 471-482.

Faraj, S., Jarvenpaa, S.L. and Majchrzak, A. (2011), "Knowledge collaboration in online communities", Organization Science, Vol. 22 No. 5, pp. 1224-1239.

Gulati, R., Puranam, P. and Tushman, M. (2012), "Meta-organization design: rethinking design in interorganizational and community contexts", Strategic Management Journal, Vol. 33 No. 6, pp. 571-586.

Haefliger, S., Monteiro, E., Foray, D. and Krogh, G. (2011), "Social software and strategy", Long Range Planning, Vol. 44 Nos 5/6, pp. 297-316.

Helfat, C.E. and Peteraf, M.A. (2009), "Understanding dynamic capabilities: progress along a developmental path", Strategic Organization, Vol. 7 No. 1, pp. 91-102.

Miles, M.B. and Huberman, A.M. (1994), Qualitative Data Analysis: An Expanded Sourcebook, Sage, Thousand Oaks, CA.

Oestreicher-Singer, G. and Zalmanson, L. (2013), "Content or community? A digital business strategy for content providers in the social age", MIS Quarterly, Vol. 37 No. 2, pp. 591-616.

Puranam, P., Alexy, O. and Reitzig, M. (2014), "What's "New" about new forms of organizing?", Academy of Management Review, Vol. 39 No. 2, pp. 162-180.

Sproull, L. and Arriaga, M. (2007), "Online communities", in Bidgoli, H. (Ed.), Handbook of Computer Networks: Distributed Networks, Network Planning, Control, Management, and New Trends and Applications, John Wiley \& Sons, Hoboken, NJ.

Teece, D.J. (2007), "Explicating dynamic capabilities: the nature and microfoundations of (sustainable) enterprise performance”, Strategic Management Journal, Vol. 28 No. 13, pp. 1319-1350.

Teece, D.J. (2010), "Business models, business strategy and innovation", Long Range Planning, Vol. 43 Nos 2/3, pp. 172-194.

Teece, D.J., Pisano, G. and Shuen, A. (1997), "Dynamic capabilities and strategic management", Strategic Management Journal, Vol. 18 No. 7, pp. 509-533.

von Krogh, G. (2012), "How does social software change knowledge management? Toward a strategic research agenda", The Journal of Strategic Information Systems, Vol. 21 No. 2, pp. 154-164.

Wagner, D., Vollmar, G. and Wagner, H.T. (2014), "The impact of information technology on knowledge creation: an affordance approach to social media", Journal of Enterprise Information Management, Vol. 27 No. 1, pp. 31-44.

Yin, R.K. (2014), Case Study Research: Design and Methods, Sage, Thousand Oaks, CA.

\section{Further reading}

Eisenhardt, K.M. (1989), "Building theories from case study research", Academy of Management Review, Vol. 14 No. 4, pp. 532-550.

Franklin, J.C., Mainelli, M. and Pay, R. (2014), "Measuring the value of online communities", Journal of Business Strategy, Vol. 35 No. 1, pp. 29-42.
Keywords:

Case study,

Dynamic capabilities, Online communities, Social media,

Multiple-case study, Strategic management, Citizen community, Customer community, Digital strategy, Innovation community 
Kane, G.C., Fichman, R.G., Gallaugher, J. and Glaser, J. (2009), "Community relations 2.0", Harvard Business Review, Vol. 87 No. 11, pp. 45-50.

Majchrzak, A. (2009), "Comment: where is the theory in wikis?", MIS Quarterly, Vol. 33 No. 1, pp. 18-20.

Zammuto, R.F., Griffith, T.L., Majchrzak, A., Dougherty, D.J. and Faraj, S. (2007), "Information technology and the changing fabric of organization", Organization Science, Vol. 18 No. 5, pp. 749-762.

\section{Corresponding author}

David Wagner can be contacted at: david.wagner@ggs.de

For instructions on how to order reprints of this article, please visit our website: www.emeraldgrouppublishing.com/licensing/reprints.htm

Or contact us for further details: permissions@emeraldinsight.com 